\title{
Functional flexibility in institutionalized sedentary older adults
}

\section{A flexibilidade funcional em idosos sedentários institucionalizados}

\author{
Michelle Matos Duarte ${ }^{1}$ \\ (ID) https://orcid.org/0000-0001-6381-6021 \\ Vicente Martínez de Haro² \\ (i) https://orcid.org/0000-0002-9753-103X \\ Ismael Sanz Arribas ${ }^{2}$ \\ (D) https://orcid.org/0000-0003-1881-1955 \\ Luis A. Berlanga ${ }^{1}$ \\ (D) http://orcid.org/0000-0002-0309-6568
}

Abstract - The aging process leads to deterioration in physiological functions, decreasing functional capacity. Since physical exercise reduces deleterious effects, measuring physical condition is necessary in older adults. The aim of this study was to verify the evolution of the range of motion in institutionalized sedentary older adults. The sample consisted of 19 volunteers aged 65-95 years who completed the Chair Sit-and-Reach test (CSR) and the Back-Scratch test (BS) to measure flexibility of the lower and upper limbs, respectively, before and after a period of 12 weeks without intervention. The results showed significant decrease during the control period (BS, $p=0.004$; CSR, $p=0.001$ ). These findings confirm that physical inactivity could lead to important loss of flexibility of institutionalized individuals, indicating decline of the elastic properties of musculoskeletal tissues and of connective tissues of joints. Therefore, the participation of institutionalized older adults in properly prescribed and guided physical exercises should be continuous and regular.

Key words: Flexibility; Older adults; Sedentary Behavior.

Resumo - O envelhecimento implica uma deterioraçâa das funçôes fisiológicas, podendo diminuir a capacidade funcional. O exercício físico poderia minimizar esses efeitos deletérios, por isso é necessário conhecer a condição física dos idosos. O objetivo deste estudo é verificar a evolução da amplitude de movimento em idosos institucionalizados e sedentários. A amostra foi composta por 19 voluntários, com idades entre 65 e 95 anos, que concluíram os testes Chair Sit and Reach (CSR) e Back Scratch (BS) para medir a flexibilidade dos membros inferiores e superiores, respectivamente; antes e depois de um periodo de 12 semanas sem intervenção. Os resultados mostraram uma diminuição significativa durante o periodo de controle ( $B S, p=0.004 ; R S E, p=0.001$ ). Esses achados confirmam que a inatividade física pode implicar uma perda significativa de flexibilidade dos idosos institucionalizados, indicando uma diminuição nas propriedades elásticas do tecido musculoesquelético e dos tecidos conjuntivos nas articulações. Portanto, a participação de idosos institucionalizados no exercício físico orientado e adequadamente prescrito deve ser continua e regular.

Palavras-chave: Flexibilidade; Idosos; Comportamento Sedentário.
1 Universidad Francisco de Vitoria. Madrid, Spain.

2 Universidad Autónoma de Madrid. Madrid, Spain.

Received: May 12, 2020 Accepted: December 19, 2020

How to cite this article

Matos-Duarte M, Martínez-de-Haro V, Sanz-Arribas I, Berlanga LA. Functional flexibility in institutionalized sedentary older adults. Rev Bras Cineantropom Desempenho Hum 2021, 23:e73816. DOl: http://doi.org/10.1590/19800037.2021v23e73816

Copyright: This work is licensed under a Creative Commons Attribution 4.0 International License. 


\section{INTRODUCTION}

The increasing age of the population requires the implementation of public, health and social policies focused on the care of the elderly. The objective of these measures should consider that the aging process should occur with the least possible deleterious effect on the functional capacity of people for the benefit of both quality of life of individuals and society itself in terms of reduction of health expenses for the care of individuals with functional impairments. In this sense, it is well known that physically active older adults are less likely of developing chronic diseases ${ }^{1}$.

All physiological changes inherent to aging can directly or indirectly influence the level of physical activity of older adults as it is a conditioner of functionality and health status of an individual ${ }^{2}$. In addition to the increased risk of diseases and injury in this age group, aging leads to difficulties in the performance of activities of the daily living (ADL) and instrumental activities of the daily living (IADL), reducing the ability to perform these tasks autonomously and independently. In other words, functionality or functional capacity understood as the physical ability to carry out normal daily activities in an independent manner and maintaining adequate physiological reserve $\mathrm{e}^{3}$ can be aggravated with aging.

Such limitations in the functional capacity of older adults can result in a situation of disability, feared on many occasions by the aging population, which struggles to accept and adapt to changes inherent to this stage of life. In turn, aging is considered to be a complex process and, in most cases, a traumatic transition phase. However, there are few studies focused on the assessment of the health status and physical condition of institutionalized older adults; although it is essential to maintain the physical condition of this population at minimum level to keep functionality and independence for satisfactory aging and with the least possible deleterious effects ${ }^{4}$. In addition, it is known that institutionalized older adults are at greater risk of suffering from loss of physical functionality in the performance of ADL and IADL compared to those who live at their homes ${ }^{5}$.

To influence the functional capacity and physical condition in the elderly, the best strategy is to use interventions based on multicomponent physical exercises. Thus, interventions based on the development of muscle strength have been shown to prevent the risk of falls ${ }^{6}$, improve performance in $\mathrm{ADL}$ and $\mathrm{IADL}^{7}$, reduce locomotion problems and gait disturbances ${ }^{8}$, among other benefits. The development of flexibility or range of motion is also essential in the elderly, as it is closely related to quality of life ${ }^{9}$, performance of daily tasks ${ }^{10}$ and improvement of functions in genera $1^{11}$.

The range of motion is impaired by aging ${ }^{12,13}$, reductions can occur in certain joints of up to $20-40 \%{ }^{14}$. In addition, sedentary behavior is another important aggravating factor of decreased flexibility ${ }^{15}$, and reduced levels could increase the risk of back pain in different populations ${ }^{16}$, important gait limitations ${ }^{8}$ and higher risk of falls in older people ${ }^{17}$.

Therefore, the American College of Sports Medicine ${ }^{18}$ highlights the 
need for older people to maintain adequate level of range of motion in all joints to preserve functional capacity, maintain greater degree of autonomy, better performance in ADL, minimize the appearance of body pain ${ }^{19}$ and maintain or improve quality of life $\mathrm{e}^{20}$.

Specifically, the flexibility of some joints such shoulder has more importance in ADL and IADL such as dressing and undressing, combing, reaching high objects, cleaning, etc., and its maintenance is crucial for the functional independence of older adults ${ }^{21}$. Similarly, minimizing the loss of flexibility in lower limbs is essential for this population, especially of hamstring muscles, since loss of flexibility negatively affects the mobility of the pelvis and leads to unwanted biomechanical changes in the distribution of pressures in the spine, allowing the appearance of postural restructuring and spinal conditions ${ }^{22}$. This situation could lead to significant limitations when sitting and standing up, bending down or changing positions; among other everyday actions.

Given the importance of flexibility for older individuals in their functional performance ${ }^{20}$ and the need to provide more data on the status of this physical component in one of the population segments with the highest risk of suffering functional dependence ${ }^{5}$, this study aims to evaluate the joint mobility of the upper and lower limbs in institutionalized sedentary older adults.

\section{METHODS}

The number of older adults who initially participated in the first application of the tests was 21 subjects, but two cases were lost in the second measurement. Therefore, the final sample consisted of 19 volunteers (11 men and 8 women) aged $65-95$ years ( $M=75.3 \pm 9.8$ years).

All participants were permanent residents of institutions for the elderly located in the city of Belo Horizonte, Brazil. Residences were private, belonging to a single owner, and offered monthly medical services, biweekly nutritionist, weekly physiotherapy, specialized caregivers and recreational activities such as board games, bingo and cards. In addition, family members could visit their relatives and leave the residence with them at any time for a walk or even for the weekend.

It is important to mention that the practice of physical activity offered by institutions was very limited and not guided by professionals. Physical activities were limited to the performance of personal care tasks, room organization, short walks through physical spaces of the institution, nonactive leisure activities and weekly physiotherapeutic service only for those who needed some type of rehabilitation procedure.

As inclusion criteria, it was established that all institutionalized participants were 65 years of age or older, functionally independent and had characteristics that, according to Cabrera de León et al. ${ }^{23}$, classified them as sedentary people. Likewise, participants should have a medical certificate for the performance of physical activities and no signs of suffering 
from musculoskeletal and cognitive limitations that could compromise the execution of movements.

It is important to mention that, before the final sample selection, an interview was carried out with the respective managers of institutions and with caregivers who were most familiar with participants to assess their functional dependence through relevant questions ${ }^{24}$ in order to make preselection consistent with the defined inclusion criteria. Regarding ethical aspects, the norms established by the Research Ethics Committee of the Autonomous University of Madrid (Spain) were respected, preserving the anonymity and confidentiality of institutions and participants. Authorizations for the study were obtained and all participants were duly informed about the objectives and procedures of the research, as well as their voluntary participation and ethical standards.

\section{Procedures}

This is a longitudinal, non-interventionist, observational study on the evolution of flexibility in sedentary and institutionalized older adults. To determine the study variable, the chair sit-and-reach test (CSR) and the back-scratch test (BS) were used in order to measure flexibility of lower and upper limbs. The aforementioned flexibility tests of the SFT test battery created by Rikli and Jones ${ }^{3}$ not only are highly reliable ( $r=0.96$ and $r=0.95$, respectively) with proven validity, but also safe and easy to apply.

A semi-open interview was conducted with each participant before the application of tests in order to find out a little more about the profile of each participant, including their physical and emotional state and level of functional independence. The administration of tests was always carried out in the morning and in institutions themselves to avoid the influence of environmental and temporal conditions. Tests were carried out twice (Pre-Test and Post-Test), with a period of 12 weeks between them, which is considered minimum to observe physiological adaptations or mismatches.

For the realization of these tests, all the protocols established by Rikli and Jones ${ }^{3}$ were respected, in regard to the previous warm-up, to provide the pertinent information to the participants about the execution of the movements, and the reproduction of the same by the evaluator to exemplify; as well as a short period of time for participants to become familiar with the movements and choose the side of preference to be evaluated, that is, the side with which the participants felt more competent. Specific standard procedures were also followed in the application of each test, its score, registration, data analysis and safety standards for execution.

The instruments used for CSR administration were a chair with a height of 43 centimeters and a $50 \mathrm{~cm}$ long ruler (with precision in $\mathrm{mm}$ ). For the development of BS, only a $50 \mathrm{~cm}$ long ruler was used (with precision in $\mathrm{mm}$ ).

\section{Statistical analysis}

The statistical program Statistical Package for the Social Sciences - SPSS for Windows in version 20.0 was used for the statistical analysis. A des- 
criptive analysis of the variables of the age of the sample was performed, in addition to the variables investigated containing the mean, maximum, minimum and standard deviations was applied for the variables and the Shapiro-Wilk test to verify the normal distribution of the data. The significance level adopted was $p<0.05$. The t-test was applied to analyze differences between Pre-Test and the Post-Test results.

\section{RESULTS}

Table 1 summarizes the results obtained in both tests and the comparison between the first and the second measurement with level of statistical significance between them.

Table 1. BS and CSR Results and Pre-Test and Post-Test Comparisons

\begin{tabular}{lc}
\hline & Results \\
\hline N (sample) & 19 \\
Male & 11 \\
Female & 8 \\
Age (years) & $75.3 \pm 9.8$ \\
BS (cm) & \\
Pre-Test & $-16.5 \pm 12.60$ \\
Post-Test & $-17.8 \pm 12.50 \dagger$ \\
CSR (cm) & \\
Pre-Test & $-13.4 \pm 10.10$ \\
Post-Test & $-15.4 \pm 10.40 \ddagger$ \\
\hline
\end{tabular}

Note. $\dagger p=0.004 ; \ddagger p=0.001$

BS and CSR Results and Pre-Test and Post-Test Comparisons
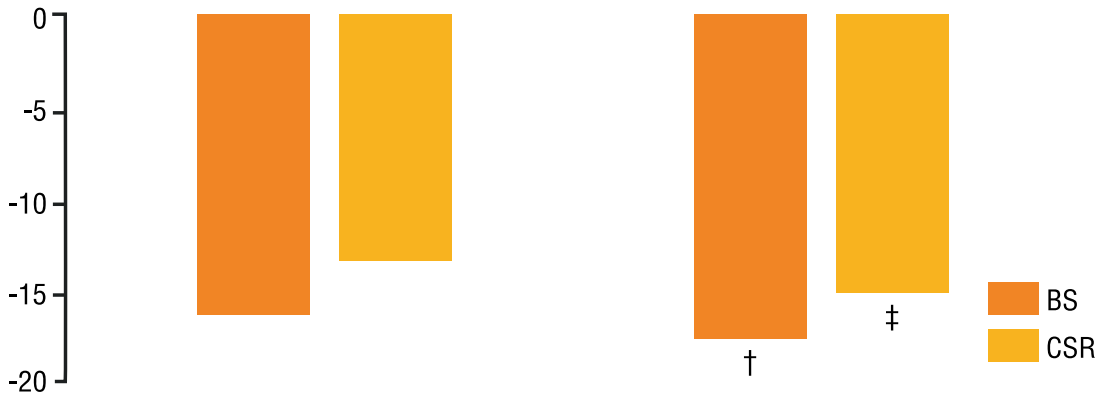

Figure 1. BS and CSR Results and Pre-Test and Post-Test Comparisons Note. $\dagger p=0.004 ; \ddagger p=0.001$

Results have shown significant loss of joint mobility in joints evaluated during the three months of the control period (BS, $p=0.004$; CSR, $p=0.001$ ).

\section{DISCUSSION}

The results of our observational study confirm that physical inactivity could lead to significant deterioration in the levels of flexibility and range 
of motion of institutionalized individuals. In this sense, it seems that the absence of physical activities directed by the institution's staff, together with the maintenance of a sedentary lifestyle by the participants of this study, in just 12 weeks of time, worsened considerably according to the results obtained in the BS and CSR tests. To these questions it is important to also add the general absence of routines and exercises aimed at improving and maintaining joint mobility that has characterized the behavior of the sample of this research. These results indicated deterioration of the elastic properties of musculoskeletal tissue and connective tissues that make up joints associated with aging, being in line with results found by other researchers ${ }^{12,13}$.

In a recent research ${ }^{25}$ that included 253 institutionalized older adults from Bogota, the authors verified that the institutionalization has negative impact on the physical condition of individuals, with CSR results of 11.4 \pm 8.2 in men and $-1.1 \pm 4.8$ in women; and BS of $-16.5 \pm 10.7$ for men and $-7.3 \pm 6.3$ for women. Despite their lack of comparisons between genders, these results are similar to those obtained here, where participants had even lower values before and after the follow-up period.

However, the aging process should not be considered as the only factor that causes reduction in the range of motion in institutionalized individuals, since the sedentary lifestyle and the restricted use of joints in the performance of daily tasks could also accentuate this reduction. Santos et al. ${ }^{15}$ observed in a sample of 312 older adults that sedentary behaviors have direct negative influence on the flexibility of the lower limbs; regardless of practice of physical activity of moderate to vigorous intensity. Thus, the authors concluded that older people who spent more time performing physical activities or less time in sedentary behaviors had better overall functional physical status.

Dogra and Stathokostas ${ }^{4}$ observed in a sample of 9,478 older adults (over 65 years of age), in addition to 10.060 middle-aged adults (45-64 years) that both regular practice of physical activity and reduction of sedentary behaviors minimize the decrease in functional capacity associated with aging. In addition, physically active older people have greater autonomy compared to sedentary people in the performance of daily $\operatorname{tasks}^{26}$, so the deterioration of certain age-related physiological functions could be delayed.

Specifically, levels of flexibility and balance have been related to both functional capacity and risk of falls among individuals over 65 years of age, concluding that the performance of a proprioceptive exercise program that improves these capacities brings important benefits to their functional status ${ }^{17}$. Likewise, it has been observed that a 12 -week training free period followed by a multi-component exercise program entails decreases in flexibility levels ${ }^{27}$; so it is possible to appreciate the involution of this skill if it does not develop properly.

In any case, none of the members of our sample reported great difficulties in carrying out daily activities, despite the reduced flexibility levels 
presented. Considering that subjects live permanently in institutions, it is possible that the daily activities carried out on a daily basis did not reflect the need to be autonomous and / or self-sufficient. In fact, Castellanos, Gómez and Guerrero ${ }^{28}$ observed that institutionalized older adults had lower fitness levels compared to those who lived in their homes, probably due to the lower need to perform daily tasks (shopping, cooking, cleaning, etc.) or also because people who begin to be more dependent are more likely of living in institutions compared to those who are more autonomous.

Regarding other important physical condition components associated with health, Preto et al. ${ }^{29}$ found significant reduction in the levels of muscle strength and control of arms and legs and in dynamic agility / balance; as well as flexibility of lower and upper limbs. The authors also observed significant reduction in self-efficacy to avoid falls after 24 months of follow-up; highlighting once again, the need to stop, slow down or minimize the decrease in the functional capacity of older adults through the implementation of multi-component exercise programs within institutions and residences, encouraging active lifestyle among residents. A possible solution to diminish detriment in physical performance for this population could be to promote Vivifrail program ${ }^{30}$ which includes both evaluation protocols and physical exercise prescription designed to attend the different physical needs for older people, including those with frailty syndrome.

As for limitations of our study, we highlight the difficulty in finding a sample that had the characteristics presented, as a result, the sample size could not be wider. Also, future research should consider intervening experimentally with the implementation of physical exercise programs aimed at developing flexibility and breadth of movement and comparing the results with a control group of the same population profile.

\section{CONCLUSIONS}

The evolution of the articular mobility of upper and lower limbs of sedentary older adults who have participated in this research has significantly decreased. It could be concluded that the loss of this physical capacity is strongly associated with the lack of physical activity and establishment of habits and lifestyles compatible with the sedentary lifestyle characteristic of people living in nursing homes. Since the well-being and quality of life of older adults largely depend on their functional capacity and level of autonomy for the performance of daily tasks, it would be advisable to implement measures aimed at both prevention and intervention focused on the improvement and / or maintenance of functional capacity.

The results of the present study are similar to those obtained in previous studies and point that institutions for older adults should offer activities that encourage participation in physical exercise programs adapted to their needs in order to improve and maintain their quality of life and functional autonomy.

Among the most effective measures to achieve this goal, multi-com- 
ponent exercise programs have proven to be safe and effective for older adults. Given the deterioration of flexibility associated with aging, these programs should consider the work of the range of motion and extensibility of muscles.

In the case of institutionalized older adults, participation in guided exercise programs, supervised and adapted to their characteristics should be continuous and regular; since due to the aging process, there is significant deterioration of different physical functions, worsened by physical inactivity.

\section{COMPLIANCE WITH ETHICAL STANDARDS}

\section{Funding}

This research did not receive any specific grant from funding agencies in the public, commercial, or non-profit sectors. This study was funded by the authors.

\section{Ethical approval}

This research is in accordance with standards set by the Declaration of Helsinki.

\section{Conflict of interest statement}

The authors have no conflict of interests to declare.

\section{Author Contributions}

Conceived and designed experiments: MMD; VMH; ISA. Performed experiments: MMD. Analyzed data: MMD; VMH; ISA; LAB. Contributed with reagents/materials/analysis tools: MMD; VMH; ISA; LAB. Wrote the paper: MMD; LAB.

\section{REFERENCES}

1. Cadore E, Pinto R, Bottaro M, Izquierdo M. Strength and endurance training prescription in healthy and frail elderly. Aging Dis 2014; 5(3):183-195.

2. Correa-Bautista JE, Sandoval-Cuellar C, Alfonso-Mora ML, Rodríguez-Daza KD. Cambios en la aptitud física en un grupo de mujeres adultas mayores bajo el modelo de envejecimiento activo. Rev Fac Med 2012; 60(1):21-30.

3. Rikli RE, Jones CJ. Senior Fitness Test Manual. Champaign: Human Kinetics; 2001.

4. Dogra S, Stathokostas L. Sedentary behavior and physical activity are independent predictors of successful aging in middle-aged and older adults. J Aging Res 2012; 2012:1-8.

5. Pinillos-Patiño Y, Prieto-Suárez E. Funcionalidad física de personas mayores institucionalizadas y no institucionalizadas en Barranquilla, Colombia. Rev Salud Publica (Bogota) 2012; 14(3):438-447.

6. Karlsson MK, Vonschewelov T, Karlsson C, Cöster M, Rosengen BE. Prevention of falls in the elderly: a review. Scand J Public Health 2013; 41(5):442-454.

7. Ribeiro LH, Neri A. Exercícios físicos, força muscular e atividades de vida diária em mulheres idosas. Cien Saude Colet 2012; 17(8):2169-2180.

8. Schenatto P, Milano D, Berlezi EM, Bonamigo E. Relação entre aptidão muscular e amplitude articular, por faixa etária, na marcha do idoso. Rev Bras Geriatr Gerontol 2009; 12(3):377-389. 
9. Sławińska T, Posłuszny P, Rożek K. The relationship between physical fitness and quality of life in adults and the elderly. Hum Mov 2013; 14(3):200-204.

10. Vale R, Novaes JS, Dantas EHM. Efeitos do treinamento de força e de flexibilidade sobre a autonomia de mulheres senescentes. R Bras Ci e Mov 2005; 13(2):33-40.

11. Stanziano DC, Roos BA, Perry AC, Lai S, Signorile JF. The effects of an activeassisted stretching program on functional performance in elderly persons: a pilot study. Clin Interv Aging 2009; 4:115-120.

12. Marques EA, Baptista F, Santos R, Vale S, Santos DA, Silva AM, et al. Normative functional fitness standards and trends of portuguese older adults: cross-cultural comparisons. J Aging Phys Act 2014; 22(1):126-137.

13. Vagetti GC, Barbosa Filho V, Oliveira V, Mazzardo O, Moreira N, Gomes AC, et al. Functional fitness in older women from southern Brazil: normative scores and comparison with different countries. Rev Bras Cineantropom Desempenho Hum 2015; 17(4):472-484.

14. American College of Sports Medicine. ACSM Position stand: exercise and physical activity for older adults. Med Sci Sports Exerc 2009; 41(7):1510-1530.

15. Santos DA, Silva AM, Baptista F, Santos R, Vale S, Mota J, et al. Sedentary behavior and physical activity are independently related to functional fitness in older adults. Exp Gerontol 2012; 47(2012):908-912.

16. Silva MR, Ferretti F, Lutinski JA. Dor lombar, flexibilidade muscular e relação com o nível de atividade física de trabalhadores rurais. Saúde Debate 2017; 41(112):183-194.

17. Martínez-López E, Hita-Contreras F, Jiménez-Lara P, Latorre-Román P, Martínez-Amat A. The association of flexibility, balance, and lumbar strength with balance ability: risk of falls in older adults. J Sports Sci Med 2014; 13(2):349-357.

18. American College of Sports Medicine (ACSM). Manual ACSM para la valoración y prescripción del ejercicio. Badalona: Paidotribo; 2005.

19. King AC, Pruitt LA, Phillips W, Oka R, Rodenburg A, Haskell WL. Comparative effects of two physical activity programs on measured and perceived physical functioning and other health-related quality of life outcomes in older adults. J Gerontol A Biol Sci Med Sci 2000; 55(2):M74-M83.

20. Gonçalves L, Vale R, Barata NJ, Varejão RV, Dantas EH. Flexibility, functional autonomy and quality of life (QoL) in elderly yoga practitioners. Arch Gerontol Geriatr 2011; 53(2):158-162.

21. Moraes EN. Atenção à saúde do idoso: aspectos conceituais. Brasília: Organização Pan-Americana da Saúde; 2012.

22. Da Silva Dias R, Gómez-Conesa A. Síndrome de los isquiotibiales acortados. Fisioterapia 2008; 30(4):186-193.

23. Cabrera de León A, Rodríguez-Pérez MC, Rodríguez-Benjumeda LM, AníaLafuente B, Brito-Díaz B, Muros de Fuente M, et al. Sedentarismo: tiempo de ocio activo frente a porcentaje del gasto energético. Rev Esp Cardiol 2007; 60(3):244-250.

24. Trigás-Ferrín M, Ferreira-González L, Meijide-Míguez H. Escalas de valoración funcional en el anciano. Galicia Clin 2011; 72(1):11-16.

25. Benavides-Rodríguez C, García-García J, Fernandez J. Condición física funcional en adultos mayores institucionalizados. Universidad y Salud 2020; 22(3):238-245.

26. Carmo NM, Mendes EL, Brito CJ. Influência da atividade física nas atividades da vida diária de idosas. Rev Bras Cienc Envelhec Hum 2008; 5(2):16-23.

27. Carvalho MJ, Marques E, Mota J. Training and detraining effects on functional fitness after a multicomponent training in older women. Gerontology 2009; 55(1):41-48.

28. Castellanos J, Gómez DE, Guerrero CM. Condición física funcional de adultos mayores de Centros Día, Vida, Promoción y Protección Integral, Manizales. Hacia Promoc Salud 2017; 22(2):84-98. 
29. Preto L, Santos AL, Mendes ME, Novo AP, Pimentel MH. Deterioro funcional, miedo a caerse y composición corporal en ancianos institucionalizados. Enferm Clin 2015; 25(2):81-86.

30. Izquierdo M. Prescripción de ejercicio físico. El programa Vivifrail como modelo. Nutr Hosp 2019; 36(N. Extra 2):50-56.

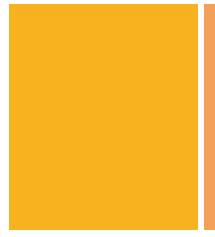

Corresponding author

Michelle Matos Duarte

Department of Physical Activity and Sports Sciences

Faculty of Health Sciences

Universidad Francisco de Vitoria. Carretera Pozuelo a Majadahonda

Km 1.800, Pozuelo de Alarcón Madrid, Spain. 28223.

Email:michelle.matos@ufv.es 